\title{
FINDING CONNECTION BETWEEN EXTENSIVE READING AND STORY WRITING
}

\author{
Ista Maharsi \\ Fakultas Psiologi dan Ilmu Sosial Budaya Universitas Islam Indonesia \\ e-mail: ista.afandi@gmail.com
}

\begin{abstract}
This paper is aimed to investigate students' vocabulary size before and after the extensive reading program and to explore whether there is a connection of extensive reading program and writing activities using Cartoon Story Maker. There were 17 students participating in this study. Data were collected from pre-test, post-test, observations, focus group discussions, and interviews. Findings show that students' vocabulary level rises by averagely 1.135 words. Students' perception on reading activities and their reading preferences change. More interestingly, the extensive reading program has given them joyful reading experiences and encouraged them to read more. Reading logbooks function as scaffolding for vocabulary learning and sentence structure awareness. In addition, Cartoon Story Maker is perceived as the tool to develop imagination into stories built up from their previous reading experiences. This study indicates that there is a connection between reading and writing through several aspects that establish reading and writing skills. The cartoon stories are inspired by the stories they read, the vocabulary they learned, the retold plots, and there is an artful blend of imagination and creativity.
\end{abstract}

\section{Keywords: extensive reading, cartoon story maker, story writing}

\section{MENEMUKAN HUBUNGAN ANTARA MEMBACA LUAS DAN MENULIS CERITA}

\begin{abstract}
Abstrak: Artikel ini bertujuan untuk menemukan jumlah kosakata siswa sebelum dan sesudah program extensive reading dan menggali apakah ada hubungan antara program extensive reading dan menulis menggunakan Cartoon Story Maker. Ada 17 siswa yang berpartisipasi dalam penelitian ini. Data diambil dari pre-tes, pos-tes, observasi, diskusi kelompok, dan wawancara. Hasil penelitian ini menunjukkan bahwa tingkat kosakata siswa meningkat rata-rata 1.135 kata. Persepsi siswa terhadap kegiatan membaca dan kegemaran membaca berubah. Yang lebih menarik lagi adalah bahwa program membaca luas ini telah memberi siswa pengalaman membaca yang menyenangkan dan memotivasi mereka untuk membaca lebih banyak. Buku kontrol membaca berfungsi sebagai pelajaran berulang tentang kosakata dan struktur kalimat. Cartoon Story Maker diasumsikan sebagai medium untuk menuangkan imaginasi cerita yang mereka dapatkan dari membaca luas. Penelitian ini mengindikasikan bahwa ada hubungan antara membaca dan menulis yang dibangun melalui pengalaman membaca sebelumnya. Cerita kartun terinspirasi oleh cerita dari buku yang mereka baca, kosakata yang mereka pelajari, alur cerita yang dikisahkan ulang, serta penggabungan imaginasi dan kreativitas.
\end{abstract}

Kata kunci: membaca luas, cartoon story maker, menulis cerita

\section{INTRODUCTION}

To respond to the great wave of $21^{\text {st }}$ century learning, classrooms are now designed to align with the technology-based instruction in which students are intensively exposed to learning using various media and strongly empowered to studentcentered learning paradigm. Mullamaa (2010) affirms that the current technology advances has demanded the mastery of technology literacy as knowledge and information sources are unlimitedly available both in print and electronic.
The information and communication technology (ICT), therefore, can be extensively used to support classroom activities, group assignment, and thereby promote student-centered learning.

The use of technology in reading and writing classes has been widely conducted in various contexts. The receptive skills (reading) and the productive skill (writing) can be possibly taught by immersing technology applications suitable for a particular context and designated learning goal. From the technology-based 
instruction, it is accordingly expected that students are able to acquire the language skills as well as the technology application in the corresponding field. However, there are a number of difficulties that many students in the EFL context have such as understanding texts. Husna (2006) investigates students' reading speed and finds that $80 \%$ of them find difficulties in vocabulary, $15 \%$ in reading comprehension, and 5\% in other areas. This, as a result, influences the reading speed which is significantly low (100 words per minutes) and even a few of them merely read less than 100 words per minutes.

Anumber of researches have been conducted to help students read better using extensive reading programs (Soltani, 2011). In addition, the use of technology to improve students' writing ability was carried out by McLaren (2003), Lin \& Yang (2011), So \& Lee (2013). Lee \& Hsu (2009) investigated the influence of extensive reading on writing and revealed significant results. A research on the use of PDA (personal digital assistance) to write was done by Vincent (2003) and finding shows that learning using technology is proven to increase students' motivation and managerial skills. Lin \& Yang (2011) tried out Wiki-based writing projects and peer feedback and found that students gained benefits from wiki on their writings. Montelongo \& Herter (2010), in addition, proved that using computer and internet encouraged students to understand texts and facilitate students' writing in science classes. Students turned to be curious for many issues, made attempts to access sources of knowledge, and complete tasks well. Little research, if at all, addresses the use of Cartoon Story Maker (CSM) in writing class, albeit its availability and easy to operate application.

Related to the teaching of the English language skills, two options are commonly used, discrete and integrated. Discrete approach means that teaching language skills separately, while integrated approach means that more than one skill is taught at the same time. This is particularly due to the fact that rarely do people use merely one skill in communication. The integration of all those skills seems to become the most appropriate approach to learn a language under the communicative and interactive paradigm (Brown, 2000). The integration of reading and writing skills, for instance, can be implemented through student-centered learning paradigm in which communication is indicated to require verbal communication but also reading and writing activities (Kumaravadivelu, 2006).

To integrate reading and writing, strategic method can be implemented in classroom (Tsai, 2006). Similarly, Krashen (2004) affirms that reading should be seen as the only way to become good readers, to develop grammatical skills, and to be good spellers.

An extensive reading program is viewed as a complimentary reading scheme that is usually conducted together with reading classes and students are encouraged to read any reading materials that interest them without being worried of tests (Davis, 1995, p. 329). It involves reading a number of books of varied topics and genre. The selection is done by the students and they can read at their most favorite moment. The range of vocabulary should be within their mastery and a reading log usually accompanies the activity (Renandya \& Jacob, 2002, p. 296). It has many advantages such as improving spelling, vocabulary, grammar, text structure, reading and writing skills, reading preference, positive attitude towards reading, and building their reading habit (Renandya \& Jacobs, 2002, p. 296). Similarly, Al-Mansour \& Al-Shorman (2014) conduct a study involving 48 students divided into control and experimental groups. The study reveals that extensive reading program has significant influence on students' writing skills. It can be implied that reading and writing have close relation and they are highly likely to be integrated into a learning process. Not only are they theoretically interconnected but also empirically supported and interrelated.

There are three positive impacts of extensive reading, namely, influencing students' convenience, reducing students' worry, and improving their intellectual values (Yamashita, 2008). Extensive reading is believed to improve students' vocabulary after 10 -week program (Soltani, 2011). Similarly, extensive reading is proven to develop students' positive attitude on reading English texts although the students are less meticulous readers. The success of a reading program depends on several factors such as how to motivate students, how to run the program, and how to monitor it (Asraf \& Ahmad, 2003)

In conducting a successful reading process, three approaches should be consideredincidental learning, explicit instruction, and 
independent strategy development. Incidental learning requires more extensive reading and listening. Explicit instruction, in addition, covers learning words in details and developing them. Meanwhile, independent strategy development includes guessing meanings from contexts and dictionary (Hunt \& Begler, 2002, p. 258). In the same vein, Walker (1997) indicates the importance of understanding the difficulty level of a text as well as students' reading level. This study opts for those three approaches proposed by Hunt \& Begler (2002) in which students get extensive reading experiences and are exposed to word study in classrooms. The difficulty level of the texts are determined in accordance with the students vocabulary level.

Extensive reading can also be related to building reading habit. This notion is supported by (Renandya \& Jacob, 2002) who deliberately argue that extensive reading is aimed to build students' reading habit through reading a large number of books of their choice and at their most convenient time. Additionally, extensive reading program can also be supplemented with a reading $\log$ that functions to monitor the reading activities, particulalry for less motivated students. Monthly regular discussion on reading difficulties can be used as an alternative to to monitor students' progress. In this study, the monitoring book which is suggested by Renandya \& Jacobs is also used and called as reading journals. In other studies, such books are called as checklist sheet (Ahmadi, 2012), a book report (Iwahori, 2008).

Krashen (2004, p. 37) confirms that reading is the way to become good readers and spellers, develop writing skills, and improve vocabulary and grammar. However, reading does not automatically lead to good writers. Some research investigating the correlation between reading and writing in the ESL and EFL contexts find that more reading may result in better writing (Lee, 2005; Lee \& Krashen, 2002). Another research was conducted to prove whether extensive reading can improve students writing skills in both EFL and ESL context (Tsang, 1996), extensive reading and fluency (Taguchi, Takayasu, \& Gorsuch, 2011) reading attitude, vocabulary (Grabe \& Stoller, 1997).

Another context for positioning this research lies on the issue of technology in learning that has been extensively conducted.
Silva (2009) uses web-based extensive reading program (w-ERP) - a research implementation of extensive reading with the internet. Some advantages are the open access of various materials in the internet, faster and easy reading, and vocabulary development.Chen (2013) investigates 89 management and engineering students on the use of extensive reading program using e-book and the reading attitude and comprehension on the texts. In addition, Grami (2013) investigates online interactive writing program for 4 weeks to 7 students. Online reading tasks, online feedback, and students' attitude towards the setting are explored. Finding shows that the interactive features can help build peer reviews, critical thinking, and identifying audience skills. It is now clear that reading and writing skills can be developed through offline and online reading mode and intensive and extensive reading scheme.

The use of technology for writing has also been investigated. There is some software to create comics, for instance, WeeWorld, Manga Avatar Face Maker, Custom Anime, Inkscape, CSM, and Comic Life (udemy blog). Only a few of them is an open source and the others are paid application with 30-day trial. CSM seems to be the only free application and the easiest to operate.

Cartoon Story Maker (CSM) is an application that can be used to create cartoon stories with conversation bubbles, picture description, and dialogues. Some available features are people characters, setting, and dialogue bubbles. Locations and characters can be replaced from any files and downloaded materials. There are two modes of the dialogueswritten dialogue and voice-based dialogue. This application is quite simple and takes only 6.56 MB and can be run in most computers. No registration and login is needed and users can modify it with more creativity work. Despite all the strengths, CSM has few weaknesses-limited features to accommodate various expressions, limited dialogue bubbles, and no audio file can be attached.

This research makes an attempt to investigate the students' vocabulary level before and after the extensive reading program and to explore whether there is a connection of extensive reading program and writing activities using Cartoon Story Maker. 


\section{METHOD}

This study opted for mixed method approach. There were 17 student participants of English language teaching department taking 5-credit Basic Reading and Writing course. The whole research took approximately 8 -month period. Data were collected from pre-test, post-test, interviews, and two focus group discussions.

There were mainly two parts of the research design. The first half of the research period dealt with the extensive reading program and the second half was allocated for the use of CSM application to create cartoon stories. The first step that students had to complete was a pre-test on vocabulary level. The test was administered in a language library and students did the test online by visiting http://my.vocabularysize.com/. This test was developed based on Paul Nation's Vocabulary Size Test and designed in collaboration with the University of Wellington. This instrument test students' receptive knowledge on vocabulary whose results can be used for designing extensive reading program (Nation, 2012). The result of the test can directly be seen and the scores were used to predict the vocabulary level of the students. The second step is the extensive reading period in which students were required to read any graded readers' selection (available in print edition and e-book) and complete reading journals to monitor their reading progress. At the end of the reading period, a post-test was administered and a focus group discussion was conducted. The scores of the pre-test and post-test were calculated to reveal students' vocabulary level. The focus group discussion, additionally, was aimed to elicit students' perception on the extensive reading program.

The second half of the research design began with training on how to use CSM to create cartoon stories. Students are required to create stories of their own or adapted stories from the book that they read. This project was designed as group works so that students have sufficient time to construct plots, design the timeline, and discuss the dialogues. The completed cartoon was submitted both in print and file. Besides the cartoon writing, students were taught to write paragraphs and short essays. A pre-test and posttest on short essay writing were also administered. The next step of this research design was focus group discussion that was aimed to reveal students' views on the creative writing process and whether there was initial connection between reading and writing throughout the process of extensive reading program and cartoon creation using CSM. To obtain deeper information on the connection between reading and writing an interview was conducted with 6 students of low, medium, and high proficiency.

\section{FINDING AND DISCUSSION Findings}

The vocabulary pre-test and post-test results are illustrated in Figure 1. From the pretest and post-test score, it can be implied that most of the students' vocabulary level increases. The highest rise of vocabulary level is 3500 words and the least rise is 100 words. Overall, themajority of students' vocabulary size increases approximately 1.135 words. However, two students' vocabulary level (student $\mathrm{K}$ and student $\mathrm{P}$ ) jump by 2200 and 1100 words respectively.

The extensive reading program which lasted for about 8 weeks was monitored through reading journals or booklet the students had to fill in. It contains the title of the book, the author, the pages, the publisher, a short synopsis, and a list of words that the students want to highlight and learn. Table 1 shows students' vocabulary level before and after extensive reading program, the increase rates, and the number of books that the students read. The books read by the students were between 5 and 20 books.

Table 2 illustrates the results of the FGD 1 conducted on October 29, 2014. It is implied that extensive reading has changed students' reading experiences and bring many impacts in terms of reading preference, sentence meaning, vocabulary, curiosity, pronunciation and spelling.

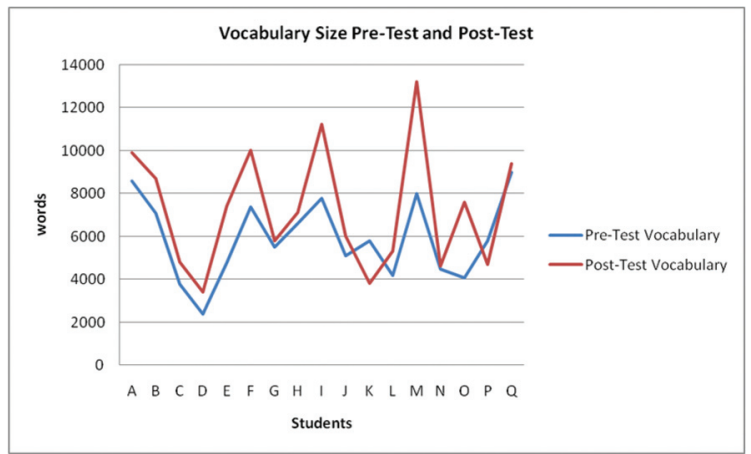

Figure 1. Pre-test and post-test results of vocabulary level 
Table 1. Students' vocabulary level before and after extensive reading program, the increase rates of vocabulary level, and the number of books that the students read

\begin{tabular}{ccccc}
\hline Student & $\begin{array}{c}\text { Pre-Test } \\
\text { Vocabulary }\end{array}$ & $\begin{array}{c}\text { Post-Test } \\
\text { Vocabulary }\end{array}$ & $\begin{array}{c}\text { Increase/ } \\
\text { decrease }\end{array}$ & $\begin{array}{c}\text { E of books } \\
\text { read }\end{array}$ \\
\hline A & 8600 & 9900 & 1300 & 5 \\
B & 7100 & 8700 & 1600 & 9 \\
C & 3800 & 4800 & 1000 & 20 \\
D & 2400 & 3400 & 1000 & 11 \\
E & 4800 & 7400 & 2600 & 14 \\
F & 7400 & 10000 & 2600 & 8 \\
G & 5500 & 5800 & 300 & 10 \\
H & 6600 & 7100 & 500 & 9 \\
I & 7800 & 11200 & 3400 & 16 \\
J & 5100 & 6000 & 900 & 20 \\
K & 5800 & 3800 & -2000 & 20 \\
L & 4200 & 5300 & 1100 & 10 \\
M & 8000 & 13200 & 5200 & 11 \\
N & 4500 & 4600 & 100 & 12 \\
O & 4100 & 7600 & 3500 & 10 \\
P & 5800 & 4700 & -1100 & 12 \\
Q & 9000 & 9400 & 400 & 20 \\
\hline
\end{tabular}

Table 2. Students' perception on extensive reading

\begin{tabular}{|c|c|}
\hline Theme & Description \\
\hline Preference & Students are more interested to read than before \\
\hline Sentence Meaning & $\begin{array}{l}\text { Students understand how to guess meanings of sentences } \\
\text { without looking up dictionary }\end{array}$ \\
\hline Vocabulary & Students perceive that their vocabulary size increases \\
\hline Curiosity & $\begin{array}{l}\text { Extensive reading increases their curiosity of the stories they } \\
\text { read }\end{array}$ \\
\hline Meaningful experience & $\begin{array}{l}\text { Students perceive that they have never had extensive reading } \\
\text { experiences }\end{array}$ \\
\hline Pronunciation \& spelling & $\begin{array}{l}\text { Students check their pronunciation and spelling using electronic } \\
\text { dictionary }\end{array}$ \\
\hline Affective & $\begin{array}{l}\text { Reading makes them happy. } \\
\text { Reading encourages them. }\end{array}$ \\
\hline
\end{tabular}

\section{Discussion}

Research findings show that vocabulary acquisition does occur through an extensive reading program (Grabe \& Stoller, 1997; Pigada \& Schmitt, 2006; Soltani, 2011). However, the vocabulary size of two students in this research (student $\mathrm{K}$ and student $\mathrm{P}$ ) decreases by 2.000 and 1.000 respectively at the post-test score. This may be due to several factors such as reading ineffectiveness, concentration, and time inappropriacy. As many as 12 books read by student $\mathrm{K}$ and 20 books were read by student
P. When noticed from the number of books, exposure seems to play roles in determining the change of vocabulary size. There seems to be a connection between the number of books read by the students and the post-test result. Student $P$ who read 20 books experience fewer numbers of vocabularies than that of student $\mathrm{K}$ who read 12 books.It seems that there is no connection between the students' vocabulary level and the number of books they read. this may be due to the fact that students chose their own books to read. Some of the students opted for reading novels they chose 
and online anime stories. It can be implied that the decrease of vocabulary level of the students in the post test does not always indicate losing vocabulary sizes, rather there may be some reasons to explain the phenomenon. Some possibilities are lack of concentration andpersonal motivation.

The story that the students read varied from 6 pages to 400 pages, including classical stories and contemporary novels. All of the selection was based on the students' options. One student asked if she (student I) was allowed to read English comics and she was definitely encouraged to do so. It happened that she was the students with the second highest vocabulary level (11.200 words) and that she loves reading since high school. Similarly, the other two students (student F and student M) with high vocabulary level were those who were very fond of reading novels orany reading materials since they were in high school. Their vocabulary sizes were 13.200 and 10.000 words respectively. Simply put, students' prior reading attitudes may influence their vocabulary sizes. Those three students reading experiences indicate that prior reading experiences and attitudes play important roles to increase the vocabulary sizes and the vocabulary mastery significantly help them to read more effectively.

From the number of books that the students read, it can be concluded that students were exposed to a range of book reading of varied difficulties. Simplified story books have significantly fewer difficulties than any original novels. From the results of pre-test and post-test, it is clear that students who read more books with high level of vocabulary difficulties have better vocabulary levels.

In this study, extensive reading was used as a treatment to increase students' vocabulary sizes, intensify students' exposure to English reading, and build students' reading habit. This extensive reading was comprehensively conducted for about 16 weeks (October-January). It was designed to prepare students to enhance students' writing abilities.

Cartoon Story Maker (CSM) was used as a medium for students to create adapted stories into a cartoon form. The stories were created by groups of 2-3 students. The students were free to adapt or modify the story plot in accordance with the illustration and features of the CSM application.

However, during the extensive reading program students found several difficulties such as understanding sentence meanings, new vocabularies, laziness, tired eyes, sleepiness, and changing mood. To overcome the problems, students force themselves to improve their reading habit, look up dictionaries, guessing meanings from contexts, find convenient place to read, and drink coffee to overcome sleepiness.

Students also perceive that several language aspects are believed to become better (three scales are used) after the extensive reading program as shown in Table 3.

Students believe that they have better reading skills due to the extensive reading requirements in which they have to read a number of books, complete reading journals, make a list of new vocabularies, and write a short summary. The reading journal activities seem to become the motivator for reading. As a result, reading speed is believed to increase because they have more exposures of language (FGD1/Question 6). As is indicated in research finding, extensive reading may influence reading speed and reading comprehension (Bell, 2001).

Meanwhile, students perceive that Cartoon Story Maker is a simple and good application. However, the software limitation does influence the result of their project. Developing story plots

Table 3. The number of students on the perceivedimprovement of language aspects

\begin{tabular}{lccc}
\hline \multicolumn{1}{c}{ Perceived improvement of language aspect } & a lot & medium & little \\
\hline Reading ability & 2 & 11 & 2 \\
Reading rate & 2 & 4 & 9 \\
Vocabulary & 3 & 9 & 3 \\
Grammar & 2 & 7 & 6 \\
Writing ability & 2 & 7 & 6 \\
Reading comprehension & 2 & 10 & 3 \\
Strategies for guessing unknown words and & 3 & 7 & 5 \\
expressions & & & \\
Thinking in English & 3 & 11 & 1 \\
\hline
\end{tabular}


and adjusting stories and the available characters are the most common.

I knew that it would be more confusing if I had to make the story by myself (I.1/ DIFF/49)

The pictures are not easy to find (I.3/ DIFF/27)

However, students found that using software for writing may turn out as a challenge and a demand at once.

I would say it is a little bit complicated [laughing] but for young people nowadays more active and demanding task is required (I.2/CHALL/81).

Perhaps it's more complicated (I.2/ CHALL/98)

Several difficulties on software use can be traced from the following interview result:

I just use the Cartoon Story Maker...the one proposed by a male friend seems more difficult although the result is better (I.1/ SOFT.NEG/41)

Uhhh....the software provides only limited pictures(I.2/LTD.SOFT/12)

There are not many choices...limited... I took the wallpaper (pictures) from the internet sources(I.2/LTD.SOFT/16)

Although many students found that using this software for creating a cartoon story is quite challenging, this activity gives positive impact such as students' autonomy.

I looked up in the dictionary... and the Cambridge electronic dictionary. They are so helpful (I.1/AUTO/21)

I checked the Cambridge dictionary and learned the sentence samples before I used them in my writing (I.1/AUTO/27)

I asked my friends whether it is appropriate or not...if not, then how to make it better... whether readers understand or not... (I.2/ AUTO/125)

I tried to find the suitable pictures by myself (I.4/AUTO/21)

From the following extracts, creativity appears to become a skill needed for making up cartoon story.

I used pictures from the internet...added some bubbles for conversations but sometimes I did not feel that the bubbles were suitable, so I changed the bubble that was not transparent (I.2/CREA/22)

I think we need to be creative(I.2/CREA/79) (I.4/CREA/160)

I used my own sentences (I.2/CREA/147) We just need to be creative. From the story books we can get the story ideas or drafts... so we don't need to be too confused (I.3/ CREA/70)

Using software for writing means using technology. This is a good activity because this activity needs creativity (I.3/ CREA/120)

Another skill that the students learn is adapting stories. However, they perceive that this may be positive and negative.

Sometimes I got stuck with ideas... when I was about to make the story like this, but I thought it should be that...that makes me confused. I also adapted my story from the books that I read... (I.2/PLOT/36) (I.2/ ADAPT/36)

Sometimes I need to adapt the pictures and the stories. Screaming is expressive already, so I think I don't need to modify(I.2/ ADAPT/115)

There is an issue of originality and activity variation found in students' interview data.

Free to create something seems more original (I.3/ORIGIN/127)

Based on the results of FGD 2, students perceive that there is a connection between extensive reading program and writing using CSM. First, extensive reading program has made them more sensitive to the use of tenses and sentence structure. This sentence structure awareness activates students' prior knowledge on sentence structure and gives sufficient exposures on various sentence structures. When they are required to write stories using CSM, the concepts are active and they can either adapt expressions or use some vocabularies in their story writing. Second, the increase of students' vocabulary sizes implies that they have more vocabulary to be used in writing stories. Those vocabulary sizes directly or indirectly have helped students to express concepts in various ways. Similar study also finds that extensive reading program 
improve students' vocabulary (Soltani, 2011) and significantly helps students in terms of vocabulary growth as well as their writing quality (Tsang, 1996). Third, students begin to love reading story books written in English. By reading much, students have more knowledge on elements of stories that can be used to write their own stories. Fourth, students have more inspiration to write. Ideas that they get from the story books encourage them to develop stories of their own using the available application. Fifth, students' exposure on tenses used in the story books can function as grammar scaffolding. When reading, they repeatedly meet the same verbs and nouns. The exposure, therefore, influences students' ability in writing. Sixth, students are inspired by the stories they read and try to build their own story through imagination. The imagination roots from ideas, plots, characters, and settings of the stories. Atligan (2013) concludes that extensive reading may enrich contents of writing and more variety of words of students' writing. In other words, extensive reading activities may help learners recognize content words in the books they read and tend to use them into their writing.

The use of CSM is believed to improve students in terms of affective domain, autonomy, and awareness. Using the CSM application is perceived as fun and interesting so that the processes of writing stories are enjoyable. In support too this research finding, Yamashita (2008) confirms that extensive reading may lead to students' convenience. It was their first time to create English cartoon stories using an application. Therefore, it is deemed as a precious experience of learning the language. By using the CSM, students make attempts to compose sentences and expressions using the correct sentence structure by checking dictionary and grammar books that they have. All those activities are self-motivated. Neither the teachers not peers require them to do so. Students also believe that one of the most important aspects of writing is writing correct sentences. It is closely related to the mechanics of writing in which appropriate tenses, vocabularies, and punctuation is concerned.

Based on the interview results, there are several important features that support the results of the FGD.

When writing dialogues, I have to ensure whether the grammar is already correct (I.1/ STRUCT.AWARE/13)
Sometimes we think of sentences in Bahasa Indonesia...so we think again whether the arrangement is not correct...for example the adjective and nouns (I.2/STRUC. AWARE/113)

When composing sentences, I am thinking of whether the expressions are appropriate (I.4/STRUCT.AWARE.65)

Referring to students' experiences in using CSM, several important issues are students' difficulties, learning autonomy, challenges, software limitation, idea adaptation, and originality. Students' difficulties that appear when they are learning indicate the existence of zone of proximal development in which independent problem solving is expected to emerge. Students who feel challenged can find solution to the problems. In other words, independent or autonomous learners can be understood as those who have willingness and ability to make choices for their own needs (Littlewood, 1996), to take control of their own learning (Zhuang, 2010), to understand their learning activities, to accept responsibilities for their learning, to take initiatives, and to take initiatives in learning activities, review and evaluate its effectiveness (Najeeb, 2013). In short, when students have intention and ability, the learning process occurs.

The issue of adaptation and adoption of ideas as well as the originality concerns with the issue of plagiarism. In writing, there must be clear boundary which is the original and which is the replication. In this study, students are allowed to adapt or adopt stories from the books they have read. However, they have to mention that the story is an adaptation. For students, original story should be highly appreciated than the adapted version.

In term of mechanics of writing, the majority of errors are found in the subject-verb agreements ( 76 errors found in 16 cartoon stories). Inappropriate word usage is counted as many as 30 errors while 24 errors are found in spelling. Lecturers, hence, should pay more attention to the subject-verb agreement in students' writing. In addition, spelling errors could have been prevented and minimized by activating the spell check features. Unfortunately, there is no spell check features in the application and students have to check using the other source. The mismatch between students' perception on the use of 
dictionary to check sentences and words does not seem to be well implemented in the case of using the CSM. They seem to use the dictionary when reading but they do not do the same thing in writing. In essence, it can be suggested that using dictionary to do spell check is important in a way that it helps improve the quality of their writing product.

Using application to create cartoon in English language may be very interesting. However, it is important to encourage students to keep checking the language as it is the only means to transfer meaning to the readers. When sentences are not well-written and vocabularies are not appropriately-selected, meanings may significantly change.

Another less challenging issue is the fact that CSM is not a publisher for students' creation. This, in fact, influences students' motivation to maximize their writing tasks. It is highly recommended that students' writing product should be published in any media such social media or YouTube. Feedback may also be meaningful for students in a way that students may feel appreciated.

\section{CONCLUSION}

The majority of student participants prefer reading books in Bahasa Indonesia than in English with light reading materials such as novel and comics as their favorites. Due to the fact that students still require external motivation to read and to change their reading habits, external reading program is helpful in encouraging their reading motivation. Ranging from 5-20 books of 6-400 pages to read during one semester, students have had the experience of exploring various story books. It indeed marks their reading exposure that they have never had before. As a result, students' vocabulary sizes change significantly. It varies from 2.400 words to 13.200 words with the average sizes of 5.912 words as indicated by the pre-test and 7.229 words as indicated by the post-test. Although the vocabulary size mastery is considered insufficient to read extensive range of academic references effectively, students have changed their reading attitudes in which reading motivation and learner autonomy improve. This change is expected to help them align with the academic reading tasks.

The connection between reading and writing revealed in this study materializes into several forms such as language awareness and writing ideas. Students' reading experiences have given them exposures on tenses, sentence structure, vocabulary, plots, topics, characters, settings, even culture which all can be processed into creative writing. Skills that are necessary to transform reading into writing may include adaptation, adoption, development, and creativity. Ultimately, technology is the tool to process all the knowledge and experiences into a more challenging product that suits the spirit of the $21^{\text {st }}$ century learning. Reading, writing, and technology seem to become a fruitful blend of skills to foster learner's creativity.

\section{ACKNOWLEDGEMENT}

Special thank goes to the Directorate of Research and Community Service (Direktorat Penelitian dan Pengabdian Masyarakat Universitas Islam Indonesia) for providing fund to conduct this research. I also thank to all students who became the participants of this research and all colleagues that have spent their time sharing and giving suggestions to this study.

\section{REFERENCES}

Ahmadi, R. 2012. "An Investigation of the Effects of Extensive Reading on the Writing Ability of EFL: Students: The Effect of Group Work." Modern Journal of Language Teaching Methods (MJLTM), ISSN: 2251 - 620414.

Al Mansour, N. S. \& Al-Shorman, R. A. 2014. "The Effect of an Extensive Reading Program on the Writing Performance of Saudi EFL University Students." International Journal of Linguistics, ISSN 1948-5425 2014, Vol. 6, No. 2, p. 247-264.

Asraf, R.M., and Ahmad, I.S. 2003. "Promoting English Language Development and the Reading Habit among Students in Rural Schools Through the Guided Extensive Reading Program." Reading in a Foreign Language, Vol. 15, 2, ISSN 1539-0578.

Atligan, A. B. 2013. "Effects of Extensive Reading on Writing in Terms of Vocabulary." ITJ, 10(1), 53-63. 
Bell, T. 2001. "Extensive Reading: Speed that Comprehension." The Reading Matrix, l(1).

Brown, H. D. 2000. Teaching by Principles: An Interactive Appproach to Language Pedagogy. $2^{\text {nd }}$ Edition. New York: Pearson Longman.

Chen, C.N. 2013. "The Effects of Extensive Reading via E-Books on Tertiary Level EFL Students' Reading Attitude, Reading Comprehension and Vocabulary." TOJET: The Turkish Online Journal of Educational Technology, Vol. 12, 2, p. 303-312.

Davis, C. 1995. "Extensive Reading: an Expensive Extravagance?." ELT Journal, Vol. 49, 4, p. 329-336.

Grabe, W., \& Stoller, F. L. 1997. "Reading and Vocabulary Development in a Second Language: A Case Study." In J. Coady, \& T. Huckin. (Eds.), Second language vocabulary acquisition: A rationale for pedagogy. (p. 98-122). Cambridge: Cambridge University Press.

Grami, M. 2013. “'Online Collaborative Writing for ESL Learners Using Blogs and Feedback Checklists." English Language Teaching, Vol. 5,10

Hunt, A. \& Beglar, D. 2002. "Current Research and Practice in Teaching Vocabulary." In Jack C. Richards and Willy A Renandya. Methodology in Language teaching: An Anthology of Current Practice. New York: Cambridge University Press, p. 258-266.

Husna, N. 2006. "Increasing the Students' Reading Speed." Proceeding of the $54^{\text {th }}$ TEFLIN International Conference. English Language Education Policies: Responding to National and Global Challenges ISSN 1916-4742 E-ISSN 1916-4750.

Iwahori, Y. 2008. Developing reading fluency: A study of extensive reading in EFL, Reading in a Foreign Language April 2008, Vol. 20, 1, p. 70-91.
Krashen, S. D. 2004. The Power of Reading: Insights from the Research, $2^{\text {nd }} \mathrm{Ed}$, London: Heinmann.

Kumaravadivelu, B. 2006.Understanding Language Teaching: From Method to Postmethod. Ney Jersey: Lawrence Erlbaum Associates, Inc.

Lee, S. and Hsu, Y. 2009. "Determining the Crucial Characteristics of Extensive Reading Programs: The Impact of Extensive Reading on EFL Writing." The International Journal of Foreign Language Teaching, p. 12-20.

Lee, S. Y. \& Krashen, S. 2002. "Predictors of Success in Writing in English as a Foreign Language: Reading, revision behavior, and writing." The College Student Journal, 36(4), p. 532-543.

Lee, S. Y. 2005. Facilitating and Inhibiting Factors on EFL Writing: A Model Testing with SEM. Language Learning, 55(2), p. 335-374.

Lin, W.C. \& Yang, S. C. 2011. "Exploring students' perceptions of integrating Wiki technology and peer feedback into English writing courses." English Teaching: Practice and Critique, Vol.10, 2, p. 88-103 Retrieved from http://education.waikato.ac.nz/ research/files/etpc/files/2011v10n2dial1. pdf.

Littlewood, W. 1997. "Autonomy: an Anatomy and a Framework." System, 24 (4), 1996, pp. 427-435.

McLaren, M. 2003. “Teacher's Response: Using Technology to Support Student Enthusiasm and Growth in Writing." School Talk, Vol. 9, 1, p.4-5.

Montelongo, J.A. and R.J. Herter. 2010. Using Technology to Support Expository Reading and Writing in Science Classes, Science Activities, 47:89-102, 2010, DOI: $10.1080 / 00368121003801388$. 
Mullamaa, K. 2010. ICT in Language Learning: Benefits and Methodological Implications, Vol. 3, 1, p. 38-44.

Najeeb, S. S. 2013. "Learner Autonomy in Language Learning." Science Direct, 1238-1242.

Nation, P. 2012. The Vocabulary Size Test. Retrieved February 5, 2016, from Victoria University of Wellington: http://www. victoria.ac.nz/lals/about/staff/publications/ paul-nation/Vocabulary-Size-Testinformation-and-specifications.pdf.

Pigada, M., \& Schmitt, N. 2006. "Vocabulary Acquisition from Extensive Reading: A Case Study." Reading in a Foreign Language, 18(1), 1-29.

Renandya, W.A., \& Jacob, G. M. 2002. "Why aren't we all doing it.In Jack C. Richard \& Willy A. Renandya. Methodology in Language Teaching: An Anthology of Current Practice." Cambridge: Cambridge University Press, p. 295-301.

Silva, J.P. 2009. "Extensive Reading through the Internet: Is it Worth the While?" International Journal of English Studies, Vol. 9 (2), p. 81-96.

So, L. \& Lee, C.H. 2013. "A Case Study on the Effects of an L2 Writing Instructional
Model for Blended Learning in Higher Education." TOJET: The Turkish Online Journal of Educational Technology, Vol 12, 4, p.1-10.

Soltani, R. 2011. "Extensive Reading: A Stimulant to Improve Vocabulary Knowledge." Studies in Literature and Language, Vol.2, 3, p.161-167.

Taguchi, E., Takayasu-Maass, M., \& Gorsuch, G. J. 2004. "Developing Reading Fluency in EFL: How Assisted Repeated Reading and Extensive Reading Affect Fluency Development." Reading in a Foreign Language, 16, p. 70-96.

Tsai, J. 2006. "Connecting Reading and Writing in College EFL Courses." The Internet TESL Journal, Vol. 12, 12.

Tsang, W. 1996. Comparing the Effects of Reading and Writing on Writing Performance. Applied Linguistics, 17, p. 210-233.

Vincent, T. 2003. "Meaningful Writing Experiences Through Handheld Technology." School Talk; Vol. 8, 3, p. 4.

Zhuang, J. 2010. The Changing Role of Teachers in the Development of Learner AutonomyBased on a Survey of "English Dorm Activity". Journal of Language Teaching and Research, 1(5), 591-595. 